\title{
THE TRANSMISSION AND RECEPTION OF THE DE INSTITUTIONE CLERICORUM
}

\section{TRANSMISSIÓ I RECEPCIÓ DE DE INSTITUTIONE CLERICORUM}

\author{
Ana B. Sánchez-Prieto \\ Universidad Complutense de Madrid
}

\begin{abstract}
Rabanus Maurus, known as primus praeceptor Germania, composed his De Institutione Clericorum in AD 819. Although in modern literature is mentioned as a sort of Liberal Arts encyclopedia, the truth is that it is rather a handbook conceived for the education of young clerics preparing for the priesthood. Rabanus' influence was wide and deep in the Carolingian Empire, as at least some parts of the Glossa ordinaria seem to come from him directly or indirectly. In this article we study the dissemination of this text, giving special attention to the preserved manuscripts and trying to discover the routes and mechanisms by which the text spread across the Carolingian Empire.
\end{abstract}

Keywords: Rabanus Maurus, Carolingian Empire, Manuscripts, Textual transmission.

\section{RESUMEN}

Rabanus Maurus, conocido como el primer praeceptor Germania compuso su De Institutione Clericorum en el año 819. Aunque en la literatura moderna se menciona como una especie de Enciclopedia de Artes Liberales, la verdad es que es más un manual concebido para la educación de los jóvenes clérigos que se preparan para el priorato. La influencia de Rabanus fue profunda en el Imperio Carolingio almenos como muestran algunas partes de la Glosa Ordinaria que parecen proceder de él directa o indirectamente. En este artículo estudiamos la diseminación de este texto prestando especial atención a los manuscritos conservados y tratando de descubrir las rutas y mecanismos mediante los cuales el texto se expande a través del Imperio Carolingio

Palabras clave: Rabanus Maurus, Imperio Carolingio, manuscritos, transmisión textual. 


\section{RESUM}

Rabanus Maurus conegut com el primer praeceptor Germania composà el seu De Institutione Clericorum l'any 819. Tot i que en la literatura moderna es menciona com una mena d'Enciclopèdia d'Arts Liberals, la veritat és que es tracta més d'un manual concebut per a l'educació dels joves clergues que es preparen per al priorat. La influència de Rabanus fou gran a l'Imperi Carolingi almenys com mostren algunes parts de la Glosa Ordinaria que semblen procedir directa o indirectament d'ell. En aquest article estudiem la dispersió $d^{\prime}$ aquest text prestant especial atenció als manuscrits conservats i tractant de descobrir les rutes i mecanismes mitjançant els quals el text s'expandeix a través de I'Imperi Carolingi.

Paraules clau: Rabanus Maurus, Imperi Carolingi, manuscrits, transmissió textual. 
The De Institutione Clericorum has come to us in different recensions, which at their time can be sub-divided into several families of manuscripts: ${ }^{1}$

1 The original form, which derives more or less directly from Rabanus' archetype in Fulda or the copy that he sent to archbishop Haistulf, without further re-elaboration (the oldest editions, together with the original text, insert an "Addition de missa" between book 1.33 and book II.2, that, however, is not to be found in any of the manuscripts with the original edition).

2 Excerpts or fragments where the original arrangement of material is not substantially altered.

3 An abbreviated version, called Rhenish recension.

4 Another epitomized version known as recension " $F$ " (=Fuldensis).

5 A reworking of part of the material (taken mostly from book I) that Rabanus composed when he already was Archbishop of Mainz (from 847) for his Chorbishop Thiotmar, under the title of De sacris ordinibus. 6 A collection of excerpts taken from book II that was included, a little altered, in Archbishop Wulfstan's Handbook.

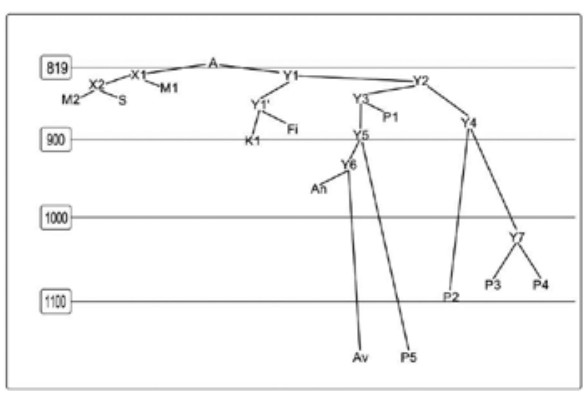

Stemma Codicum of the De Institutione Clericorum, according to Detlev Zimple.

1 This article is a re-elaboration of the chapter dedicated to the same matter in my Ph. D. dissertation of 2014. It relies heavily on Detlev Zimpel's introduction to his edition to the De institutione clericorum, 1996, pp. 160-270. However, I have tried to approach Zimpel's information from a very different perspective, and to synthesize the overwhelming amount of details provided there in less than one forth the pages it takes there. 


\section{RABANUS' ORIGINAL}

To the first group, i.e., the original and mostly unchanged text, belong the following manuscripts, grouped by branches (see fig. attached with the stemma codicum as reconstructed by Zimpel):

A first branch (Zimpel's X) is formed by:

1.1 M1 Munich, Bayerische Staatsbibliothek, Lat. 14210. Origin: first third of the $9^{\text {th }}$ century, Fulda (identified as Ms. M in Alois Knoepfler's edition). Written in Carolingian and Insular hands. After 1028 was in St. Emmeram, Regensburg (ZIMPLE, 1996: 100; KOTTJE, 1975: 540, n. 44).

1.2 M2 Munich, Bayerische Staatsbibliothek, Lat. 14405. Origin: second quarter of the $9^{\text {th }}$ C., Regensburg (identified as Ms. M1 by Knoefler).

1.3 S St. Gallen, Stiftsbibliothek, 286. Origin: second quarter of the $9^{\text {th }} \mathrm{C}$., Regensburg, written by the same hand than $M 2$.

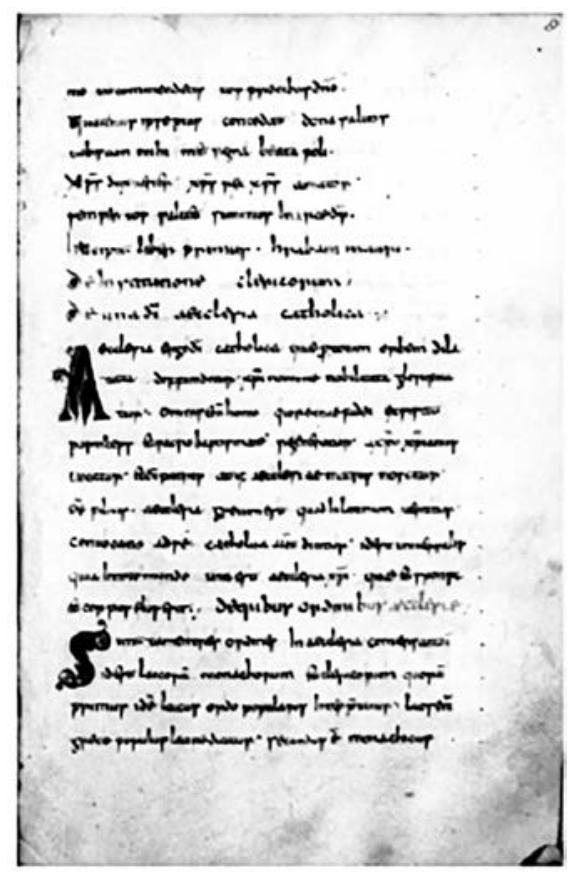

Manuscript Ml, fol. 8r. from: http://daten.digitale-sammlungen.de/bsb00036060/image_17 
$\mathrm{M} 2$ and $\mathrm{S}$, although none of them can be considered a copy of the other, are so similar in their readings that can be considered sister manuscripts, being both copies from a common exemplar (called X2 by Zimpel), which at its time was very closely related to the exemplar of $M 1$ (called $X 1$ by Zimpel).
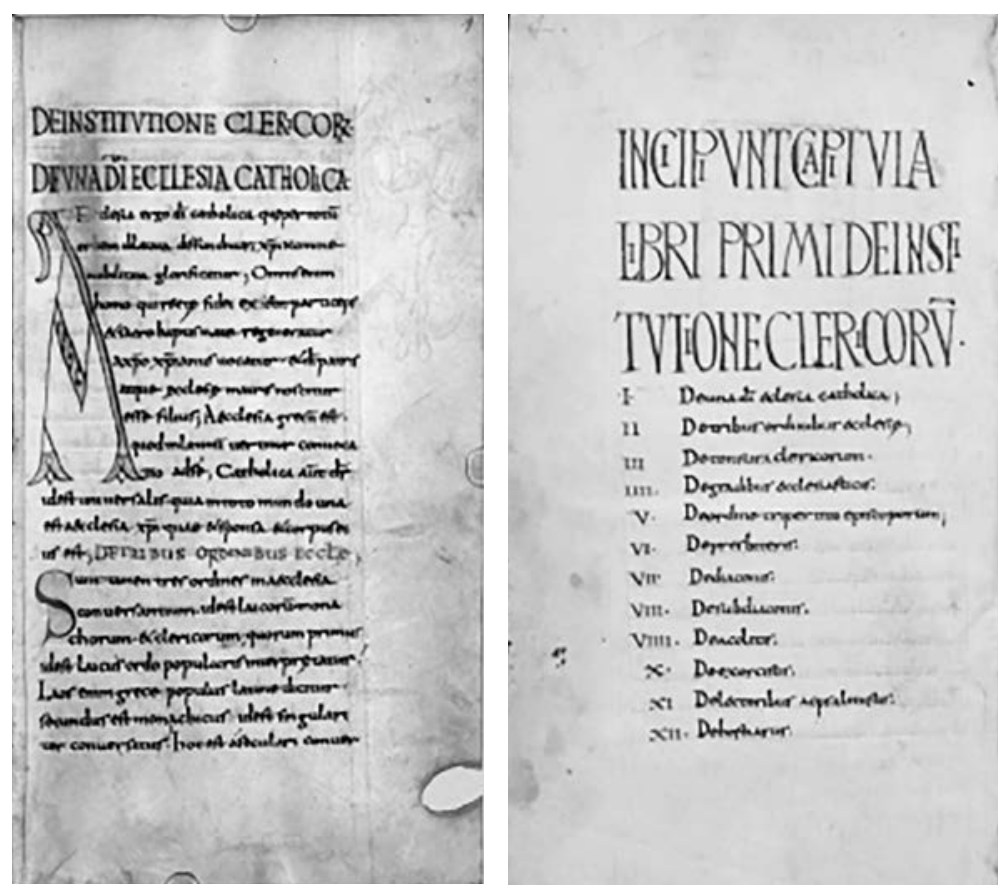

Left: Manuscript M2, fol. 4r. Retrieved from:

http://daten.digitale-sammlungen.de/ db/0004/bsb00046499/images/index.htmle

Right: manuscript $\mathrm{S}$, fol. $4 \mathrm{v}$. Retrieved from:

http://www.e-codices.unifr.ch/en/csg/0286/4/medium

In a second branch, quite more developed and where a majority of cases the lectio difficilior occurs in the variants, come the following manuscripts, ${ }^{2}$ listed roughly in chronological order:

2 For a codicological and palaeographical descriptions of all the codices here quoted see ZIMPEL, 1996: 160-230, where the codices are listed in alphabetical order of the library where they are preserved. 
$1.4 \mathrm{Pl}$ Paris, Bibliothèque Nationale, Lat. 1938 (fols 172v-178v) (I, 1-2) and Lat. 2440 (the rest) (Identified as Ms. P by Knoepfler). Origin: second half of the $9^{\text {th }}$ century, Bourges.

$1.5 \mathrm{Fi}$ Florenz, Bibl. Med. Laur., Ashburnham, 8 (43-9), Origin: third quarter of the $9^{\text {th }}$ century, West Germany. The writing has symptoms that allow us to think of an Insular exemplar. In the case of this manuscript, we are indeed in front of a quite extraordinary version because it follows the so-called Redaction " $F$ " in book I, 11-20 and 22-24 and book II, 2-15, and the original version in the rest.

$1.6 \mathrm{~K} 1$ Cologne, Erzbischöfliche Diözesan- und Dombibliothek, 110. Origin: end of the $9^{\text {th }}$ century or beginning of the $10^{\text {th }}$, Cologne.

1.7 An Angers, Bibliothèque Municipale, 301 [292]. Origin: 10 th century, Angers (St. Aubin).

1.8 P2 Paris, Bibliothèque Nationale, Lat. 2399 (fols. 112r-183r) (Identified as P1 by Knoefler). Origin: last quarter of the $11^{\text {th }}$ century, Moissac.

1.9 P3 Paris, Bibliothèque Nationale, Lat. 2441 (fols. 1 r-51 ra). Origin: $11^{\text {th }}$ century.

1.10 P4 Paris, Bibliothèque Nationale, Lat. 2442 (fols. 1 r-52r). Origin: $11^{\text {th }}$ century.

1.11 P5 Paris, Bibliothèque Nationale, Lat. 2861. Origin: $12^{\text {th }}$ century, maybe North-West France.

1.12 Av Avranches, Bibliothèque Municipale, 114. Origin: $12^{\text {th }}$ century, Mont-St.-Michel.

Also within this branch, several of the surviving manuscripts can be grouped in pairs of sister manuscripts, copied from a common exemplar, now lost. These are Fi-K1 (copies of Zimpel's Y 1'), An-Av (of Y6) and P3-P4 (of Y7). Of the rest, $P 2$ is a sister of $Y 6$ (that is, An-Av parent), both being descendant of a hypothetical $Y 5$, which at its time would have been a sister manuscript of $\mathrm{P1}$; and finally, P2 is so to say a sister of $\mathrm{Y} 7$ (parent of P3-P4). For a visual representation of the relations between manuscripts, one should resort to Zimpel's stemma codicum, inserted here as well. The need of $\mathrm{Y}^{\prime}$ rests on very few variants common in $\mathrm{Fi}$ and $\mathrm{K} 1$ that are absent from the rest of the manuscripts of this branch, all of which derive ultimately from $Y 1$; on the other side, $Y 1^{\prime}$ could not have been a direct copy of the archetype $(A)$, because in a few cases the readings offered by $X 1$ seem to be better than those of $Y 1-Y 1^{\prime}$, and if these two got the errors independently of each other it is necessary to suppose that they were already present in $A$, in which case 
there is no way to explain the fact that $X 1$ has the correct reading. Finally, it must be added that the copyist of $Y 7$ inserted so many changes in the text that with hardly any exceptions its two daughter manuscripts (P3-P4) are rendered useless for any critical edition.

\section{EXCERPTS AND FRAGMENTS}

The existing excerpts and fragments and the chapters there contained are listed here:

2.1 Budapest, Landesbibliothek im Nationalmuseum, Lat. Med. Aev. 316 (fol. 52v) (I, 14-16 beginning). Origin: first half of the $9^{\text {th }}$ century, Salzburg.

2.2 Basel, Universitätsbibliothek, F III 15 e (fols. 165-25v) (I, 32, 33; II, $1-8,35,36 ; 1,6$; II, 32, 33, 23, 24, 47, 11 (this last not entirely) (Knoepfler's Ms. B). Origin: middle $9^{\text {th }}$ century, most probably Fulda (Bischoff). Its hand shows Insular symptoms, and the text seems to be near $X 1$ in the stemma.

2.3 Munich, Bayerische Staatsbibliothek, Lat 14716 (fols. 105r-1 18v) (excerpt of I, 21, 14-23). Origin: second half of the $9^{\text {th }}$ century, maybe in the Fulda area. The text could be placed in the stemma after $Y 1$ but before Y2 (Zimplel, 1996, p. 97, 248).

2.4 Vatican, Biblioteca Apostolica Vaticana, Pal. Lat. 294 (fols. 101 r-1 18 r) (I, 1-24; II, 1-9, I, 26-30; II, 14, 15, 29, 17-24), although clearly in the $Y$ side of the stemma, cannot come from below Y2. Origin: $10^{\text {th }}-11^{\text {th }}$ century. Ownership mark that could be of Lorsch.

2.5 Vatican, Archivio di S. Pietro, H 58 (fol. 129v) (excerpt of I, 30). Origin: around the year 1000, surroundings of Rome.

2.6 Munich, Bayerische Staatsbibliothek, Lat. 6425 (fols. 203r-208r) (extract of $\mathrm{I}, 14-23)$. Origin: first fourth of the $11^{\text {th }}$ century, Freising. The text is also X1 related.1023-1039, Freising.

2.7 Vatican, Biblioteca Apostolica Vaticana, Reg. Lat. 421 (fols. 17-19) (excerpt of I, 15-23). Origin: $11^{\text {th }}$ century.

2.8 Munich, Bayerische Staatsbibliothek, Lat. 4112 (fols. 129v-130v) (extract of $1,14-23$ ). Origin: middle of the $12^{\text {th }}$ century. The text is also X1 related.

2.9 Vatican, Biblioteca Apostolica Vaticana, Reg. Lat. 1149 (fols. 1r-15v) (III, 1-2, 18-20, 26-37) belongs also to the $Y$ side but further is not possible to establish. Origin: end of the $12^{\text {th }}$ century, Esrom (Denmark). 
2.10 Vienna, Österreichische Nationalbibliothek, 1640 (fols. 135v-136v)

$(I, 15-23)$ falls again in the $X$ side. Origin: $12^{\text {th }}$ century.

As far as it is possible to say, all these excerpts seem to follow the original redaction; however, it is possible that in those cases where the excerpted material is common to both the De Institutione Clericorum and the De Sacris Ordinibus the original source is the latter instead of the former work.

\section{The Rhenish Recension}

In this version, chapter beginnings remain for the most part unaltered, but the text has been shortened, many Bible quotations omitted, and book III is missing altogether. In Düsseldorf, Trier, London and Cologne Dombibliothek book I,33 is complemented with the "Additio de Misa" consisting on extracts of Amalar's Liber officialis 3,31.

The manuscripts that have transmitted this redaction are listed below:

3.1 Düsseldorf, B 113 (fols. 6v-44r). Origin: second or third third of the $9^{\text {th }}$ C., Rhineland (?).

3.2 Erfurt, $2^{\circ} 64$ (fols. 102r-107r) (up to I, 32). Origin: end of the $9^{\text {th }}$ century, North-East France; provenience: Cologne.

3.3 Trier, 592/1578 (fol. 2r-38v). Origin: end of the $9^{\text {th }}$ century, maybe St. Maximin of Trier.

3.4 Wölfenbüttel, 32 Helmst (fols. 117v-122r). Origin: beginning of the $11^{\text {th }}$ century, probably Hildesheim.

3.5 Cologne, Dombibliothek, 81 (fol. 63r-64v) (I, 15-24, 33) (Knoepfler's Ms. C). Origin: $11^{\text {th }}$ century, Lower Rhine.

3.6 London, Harley 101 (fols. 94r-1 19v). Origin: end of the $12^{\text {th }}$ century, may be Germany; provenance: St Mary in Reading.

3.7 Cologne, Historisches Archiv der Stadt, W* 101 (fols. 55r-70v). Origin: end of the $12^{\text {th }}$ or beginning of the $13^{\text {th }}$ century, Cologne (Benedictine abbey of St. Pantaleon).

Of all seven only Düsseldorf, Trier and London contain the whole version; the rest have gaps.

As for the determining variant readings, all the manuscripts of this Rhenish redaction fall in the $\mathrm{Y}$ side of the stemma, nearer $\mathrm{K} 1$ than any other existing manuscript. 


\section{THE "F" RECENSION}

This recension, baptised as " $F$ " by Knoepfler after manuscript Fulda, Aa 2, is the most widespread version of the De Institutione Clericorum, and the best represented since it has been preserved (at least partially) in not less than 22 manuscripts:

4.1 Munich, Bayerische Staatsbibliothek, Lat. 14754 (fols. 96r-118v) (I-III, 4, being the most complete manuscript of this version). Origin: second half of the $9^{\text {th }}$ century, maybe Reichenau. Ownership mark: Istum librum tradidit Longapertus ad S. Hemmeramum pro Tutone episcopo et pro remedio animae suae.

4.2 St Paul im Lavanttal, Archiv des Benediktinerstiftes, 5/1 (fols. 150v-168v) (books I and II). The writing shows insular influence. Origin: second fourth or second third of the $9^{\text {th }}$ century, Upper Italy; provenience: Reichenau and St. Blasien afterward.

4.3 Fulda, Hessische Landesbibliothek, Aa 2 (fols. 140v-151r) (book 1 , extremely summarized and II, 52, 53, 14, 15, 17, 19, 26, 28, 29, $32,37,41-46,48)$ (Knoepfler's Ms. F). Origin: year 865 (entry "finit DCCCLXV" in fol. 126v), around Bodensee.

4.4 St. Gallen, Stiftsbibliothek, 446 (pp. 74-79) (I, 14-24, 31-33). Origin: third fourth of the $9^{\text {th }}$, St. Gallen.

4.5 Bamberg, Staatsbibliothek, Lit. 131 (fol. 50v-54v) (book I, 14-24, 31-33). Origin: end of the $9^{\text {th }}$ century, South Germany, according to B. Bischoff.

4.6 St. Gallen, Stiftsbibliothek, 140 (p. 340-343) (excerpt of I, 14-23). Origin: end of the $9^{\text {th }}$ century.

4.7 Wolfenbüttel, Herzog August Bibliothek, 676.2 Novi (fols. 1 r-17v) (I, 1-33, II, 1-6, 11-19, 24-29, 31, 34-36. Origin: $9^{\text {th }}-10^{\text {th }}$ century; provenience: Braunschweig, Kollegiat-Stift.

4.8 Berlin, Staatsbibliothek, Hamilton, 290 (fols. 97v-98r) (book I, 2529). Origin: second half of the $10^{\text {th }}$ century, Upper Italy.

4.9 Wolfenbüttel, Herzog August Bibliothek, 75 Weißenburg (fols. $19 r-21$ r) (l, 24-31). Origin: second half of the $10^{\text {th }}$ century, Weißenburg.

4.10 Einsiedeln, Stiftsbibliothek, 110 (pp. 82-87) (I, 14-24, 31-33). Origin: $11^{\text {th }}$ century.

4.11 Munich, Bayerische Staatsbibliothek, Lat. 14581 (fols. 95v-97r) (l, 14-24, 31 ). Origin: $11^{\text {th }}$ century, St.Emmeram/Regensburg.

4.12 Paris, Bibliothèque Nationale, Lat. 2856 (fols. 80r-82v) (I, 1424, 31-33). Origin: $11^{\text {th }}$ century. 
4.13 Vatican, Biblioteca Apostolica Vaticana, Vat. Lat. 1146 (fols. 18va-19rb, 55vb-58rb) (excerpts from I, 14-24, 31-33). Origin: $11^{\text {th }}$ century, Italy.

4.14 Vatican, Biblioteca Apostolica Vaticana, Vat. Lat. 1147 (fols. 20va-21 rb, 62va-65ra) (excerpts from I, 14-24, 31-33). Origin: $11^{\text {th }}$ century, Central Italy.

4.15 Oxford, Bodleian Library, Holkham Misc. 17 (fols. 18va-19rb, 58ra-vb, 60rb-va) (l, 14-24, 31-33). This codex is parallel to the Vaticani Latini 1146, 1147 and 1148. Origin: second half of the $11^{\text {th }}$ century, Middle Italy.

4.16 Vienna, Österreichische Nationalbibliothek, 914 (fols. $11 \mathrm{v}-12 \mathrm{v}$, $64 \mathrm{v}-68 \mathrm{v}$ ) (excerpts from I, 14-24, 31-33). Origin: second half of the $11^{\text {th }}$ century, Upper Italy.

4.17 Vienna, Österreichische Nationalbibliothek, 1761 (214v-216v) (I, 14-23). Origin: $11^{\text {th }}-12^{\text {th }}$ century.

4.18 Vatican, Biblioteca Apostolica Vaticana, Vat. Lat. 1148 (fols. 19rb-20va, 60rb-63ra) (excerpts from I, 14-24, 31-33). Origin: $12^{\text {th }}$ century.

4.19 Bamberg, Staatsbibliothek, Lit. 140 (fol. 19r) (book I, 31). Origin: $12^{\text {th }}$ century.

4.20 Munich, Bayerische Staatsbibliothek, Lat. 21568 (fols. 79vb$89 \mathrm{va})(\mathrm{l}, 24-27)$. Origin: $12^{\text {th }}$ century; provenience: Weihenstephan (Freising).

4.21 Rome, Biblioteca Casanatense, Cod. 1405 (fols. 37vb-38rb, 38rb-40rb) (I, 14-24, 31). Origin: $12^{\text {th }}$ century, Central Italy: Umbria or Rome.

4.22 Paris, Bibliothèque Nationale, Lat. 14993 (fols. 100r-103r) (I, 25-28, partially). Origin: 12-13 $3^{\text {th }}$ century, probably France or Upper Italy, maybe Vercelli; ownership mark of St. Victor of Paris.

This recension, which finishes in book III, chapter 4, is still more reduced than the Rhenish one. Some quite long text sections have been totally swept away or summarized in just few words, and the Bible quotations reduced to the minimum necessary; relative clauses are substituted by participles... Some chapters, like the very long last one about the heresies at the end of book II, have totally vanished. In some other cases, the material has been rearranged in order to economize space. One characteristic of Rabanus' style is to offer in the beginning of a chapter the overall explanatory terms and to come back afterward to the same concepts augmented with specific details. 
The anonymous editor keeps the initial concept, but finishes it immediately with the same material provided by Rabanus, and then passes to the second concept, and so on. Surprisingly enough the four remaining chapters from book III are virtually identical to Rabanus' original composition.

As terminus ante quem, this recension was composed is year 865 , the date of Ms. Fuldensis Aa 2, but this presupposes an earlier exemplar.

\section{Rabanus' De SACRIS ORDINIBUS}

This adaptation of parts of materials performed by the same Rabanus when he had already been ordered Archbishop of Mainz for his Chorbishop Thiotmar, contains basically book I of the De Institutione Clericorum in its original fashion, to which some new chapters are added.

The De Sacris Ordinibus has been preserved in the following manuscripts:

5. 1 Vienna, Österreichische Nationalbibliothek, 1073 (Knoefler's Ms. V). Origin: middle of the $9^{\text {th }}$ century.

5.2 Metz, Bibliothèque-Médiathèque, 351 (fols. 1v-42r). Origin: second half of the $9^{\text {th }}$ century; provenience: St. Arnulf of Metz.

5.3 Munich, Bayerische Staatsbibliothek, Lat. 14728 (fols. 49r-126v). Origin: $10^{\text {th }}$ century; provenience: St. Emmeram/Regensburg.

5.4 Vienna, Österreichische Nationalbibliothek, 1050 (fols. 1v-4Or). Origin: first half of the $12^{\text {th }}$ century; provenience: Salzburg.

5.5 Dresden, Sächsische Landesbibliothek, A 132 (fols. 1v-4Or) (Knoefler's Ms. D). Origin: $12^{\text {th }}$ c., Münstereifel.

5.6 London, British Library, Arundel 360 (fols. 32r-41v). Origin, 12 $12^{\text {th }}$ century,

In those passages taken from De Institutione Clericorum, the textual variants look to be akin to $Y 1$.

\section{The ENGLish CONNEXION}

There are some excerpts that clearly do not belong to the main or original recension, but that have been transmitted within Archbishop Wulfstan's Handbook, which for its variant readings is quite far from the original tradition of the De Institutione Clericorum (SAUER, 1980: 341-384).

The list of the manuscripts that contain these excerpts is the following:

6.1 Cambridge, Corpus Christi College, 190 (pp. 205-211) (II, 1-10). 
Origin: first half of the $11^{\text {th }}$ century, Exeter (England).

6.2 Oxford, Bodleian Library, Barlow 37 (fols. 37r-39r) (II, 1-10). Origin: end of the $12^{\text {th }}$ century or beginning of the $13^{\text {th }}$, England, maybe Worcester.

6.3 Cambridge, Corpus Christi College, 265 (pp. 194-197) (excerpt of II, 1-7). Origin: $11^{\text {th }}$ century, Worcester.

6.4 Cambridge, Pembroke College, 25 (fol. 159r-165v) (II, 1-10). Origin: $11^{\text {th }}$ century, England (provenance: Bury).

\section{LOST MANUSCRIPTS}

To start with, we have lost Rabanus' archetype (7.1) (A in the stemma codicum). One could argue that it could have gone to Archbishop Haistulf, but that is improbable, mainly because Rabanus specifies in his prologue that he undertook the task of composing it to the benefit of the brothers preparing for receiving the holy orders, and besides he seems to have considered the De Institutione as a working text for himself, as is proven by the fact that he reused it for his De Sacris Ordinibus. Another question is if Rabanus' original manuscript ended up in Mainz when he was consecrated archbishop there, which is a quite reasonable thought, but comes up against the fact that in its variants De sacris ordinibus agrees with the readings of $Y 1$, and therefore one should conclude that Rabanus left the original in Fulda and took with him a copy of the "Y" branch (which we shall consider as 7.2).

Mainz must have had also at least the copy that Rabanus gave to Archbishop Haistulf (7.4), maybe on the occasion of the consecration of the new church in Fulda, on November the first 819. And we have already speculated with the idea that Rabanus could have taken another copy with him when he was ordained archbishop in that see.

From comparing the existing manuscripts, we already came to mention some others that have perished, but whose existence is needed to justify the differences in the readings of the surviving ones. Here are they listed, together with the few hints that can be added in relation to their date and place of origin.

$7.4 \times 1$. Must have been in Fulda, since there it served as the model for M1. In spite of being a very early copy, almost contemporary to Rabanus' original manuscript, it was a careless one.

7.5 X2. Copied from X1 also in a very early stage, since served as a model for $M 2$ and $S$, that are dated in the second quarter of the $9^{\text {th }}$ century; and because these two were written in Regensburg, we can 
pose the hypothesis that ether it was copied in Fulda and shortly after exported to Regensburg, or copied in Regensburg from an exemplar borrowed from Fulda.

7.6 Y1. Copied at a very early stage, and probably directly from A, was indubitably a very good copy, almost error-free (ZIMPEL, 1996: 99, can only find three readings that presumably were more accurate in $X 1$ than in $Y 1$ ), and its writing must have had Insular elements, for which cannot go further than the middle years of the $9^{\text {th }}$ century, and for the same reason it must come from one of the Irish or Anglo-Saxon monastic foundations in the Continent, and Fulda still is the most reasonable place to consider.

7.7 $\mathrm{Y} 1^{\prime}$. Must have shown still some Insular influence in its palaeography (ZIMPEL, 1996: 95, 175f, 179-181, 267), what is already a clue of its early origin, probably still in the first half of the $9^{\text {th }}$ century, although if this comes from having being copied in a scriptorium with Insular influence or it is just consequence of a slavish copying process from its model we cannot say. Because it is the parent of Fi (West Germany, $9^{\text {th }} \mathrm{c} .2 / 2$ ) and $\mathrm{K} 1$ (Cologne, $9^{\text {th }} \mathrm{c}$. ex. or $10^{\text {th }} \mathrm{c}$. in.) we could venture that it was already native from the Rhenish area or at least that it had traveled there to serve as (partial) model for Fi still before the end of the $9^{\text {th }}$ century. Zimpel (1996: 240-241) cautiously adds that it is possible that this manuscript could have been among the losses that the Cathedral library of Cologne suffered after Hittorp's edition, since he specifies that he had used two manuscripts from the Cathedral Library of Cologne and that none of them contained the "Additio de missa" (1996:148-149).

7.8 Y2. Probably not later than 850 , since $P 1$ is from the second half of the $9^{\text {th }}$ century, and between $Y 2$ and $P 1$ is at least $Y 3$. Regretfully, its birthplace must remain unknown.

7.9 Y3. In any case must have been copied before the P1, which dates from the second half of the $9^{\text {th }}$ century. Because $\mathrm{Pl}$ comes from Bourges, its model must at least being there at a certain point of its existence, and because all its existing descendants (An, Av, P5) are of French origin $Y 3$ must have remained on French floor, at least to be copied for $Y 5$ as well.

7.10 Y4. Zimpel places it in the stemma codicum somewhat earlier than year 900 , and because in the $11^{\text {th }}$ century in Moissac it served as an exemplar for P2, must have made its way to it between ca. 900 and ca. 1000; it is therefore not abusive to pose for it a French.

7.11 Y5: As exemplar for P5 and Y6, was surely older than An, 
which is itself from the $10^{\text {th }}$ century. Its only surviving descendant is P5, native maybe of the North-West area of France, although of the $12^{\text {th }}$ century. If - as we have ventured - its model (Y3) was already French, so Y5 must have been as well.

7.12 Y6. As parent manuscript of An must have been in existence somewhat after year 900 . Again it must have been French if again our supposition of a French origin for $\mathrm{Y} 5$ and $\mathrm{Y} 3$ is correct.

7.13 Y7. This was quite a defective copy, or its copyist took too many liberties in the process. Zimpel places it in time shortly after the year 1000 , but nothing can be ascertained in relation to its birthplace.

7.14 And there must have been more copies in Fulda or in its surroundings, apart from the defective ones in the $X$ side of the stemma codicum, since Munich, Lat. 14716 (that according to Bischoff could have been copied in the area of Fulda) has to be located somewhere between $Y 1$ and $Y 2$.

And finally it is still possible to recover a handful of dispersed pieces of information about some other copies that are now lost:

7.15 Humbert of Würzburg refers to the De Institutione Clericorum in a letter sent to Rabanus (MGH, Ep. 5, Epistolae Karolini aevi III, pp. 439440). Obviously it was a complete version, and also obviously from the $9^{\text {th }}$ century. Given the fact that Humbert shows a true enthusiasm, we may take for granted that he owned a copy, which might have been done in Würzburg or anywhere else. Because of the dates it is not impossible that Humbert's copy is indeed our M2 or S, but this doesn't seem very probable, and therefore we count it among the lost manuscripts.

7.16 Among the books listed in Sankt-Gallen in 841-872 is a Rhabani de Ordinibus Ecclesiasticis. (LEHMAN, 1918: 89), which must have been a copy of the De Sacris Ordinibus. Again, it is not impossible that this book is actually Viena, Österrieichische National bibliothek, 1073 , but it is not probable.

7.17 The library catalog of Lorsch, from the end of the $9^{\text {th }}$ century, also mentions a manuscript of the De Institutione Clericorum (BECKER, 1885: 82; KOTTJE, 1975: 542).

7.18 Rebdorf (diocese Eichstätt) mentions a De Institutione Clericorum, together with some other works of Rabanus' in its catalog of around 1500 (RUF, 1933: 300).

7.19 Corvey owned a miscellaneous manuscript that among other 
titles included the De Institutione Clericorum. In 1783 was still existing, as Joh. Bapt. Enheuber could see it (LEHMAN, 1962: 128).

7.20 A Rabanus De Institutione Clericorum is listed in the catalog of the Bibliotheca monasterii cuiusdam Anglici, of the $12^{\text {th }}$ century. From the meager information offered by this list it is not possible to ascertain anything about the age or homeland of this manuscript, but it is still a good proof that the complete recension of the De Institutione Clericorum (and not just Wulfstan's recension) was known in England in the $12^{\text {th }}$ century, if not earlier.

7.21 St. Maximin of Trier had around 1100 a Rabanus de ecclesia catholica (BECKER, 1885: 180), which probably was a copy of the De Institutione Clericorum, although it is not impossible that it was a De Sacris Ordinibus or even De Ecclesiastica Disciplina.

7.22 It is assumable that the Rab' de sacramentis et sententiae quaedam in $1^{\circ}$ vol. owned by Prüfening (Regensburg) in 1158 (BECKER, 1885: 213) was also a De Institutione Clericorum.

7.23 In the $12^{\text {th }}$ century, Steinfeld owned what would seem a Liber de Sacris Ordinibus (BECKER, 1885: 218).

7.24 Constance in 1343 had a liber parvus de litera antiqua de ordinacione clericorum et baptisteriorum (LEHMAN, 1918:197). By no means is it sure that it was a De Institutione, but it is not impossible either.

\section{Reception of the De Institutione Clericorum}

The mere existence of the Rhenish recension and the recension $\mathrm{F}$ of the De Institutione Clericorum points already in the direction that our treatise was considered as a study book widely accepted, at least in sacramental and ecclesiastical matters. It should be therefore surprising if our author did not exert some influence on later authors also concerned with educational issues within the ranks of the Catholic hierarchy.

Some of the authors that show this influence as listed in the following lines: ${ }^{3}$

8.1 Pseudo-Bede's De septem ordinibus, included in the second part his Exerptiones partum, flores ex diversis quaestiones et parabola, which is a varied assortment of queries, ${ }^{4}$ a short piece about the clerical

3 Unless something else is mentioned, these lines are taken from Zimpel (1996: 113-139), where some readings are also compared. However some short indications have been added here in order to place the authors in their geo-temporal context. 
dress drawn apparently from recension " $\mathrm{F}$ " -although there is still a possibility that the " $F$ " recension draws from Pseudo-Bede, and not the other way around (ZIMPEL, 1996: 113-116)-. Bayles and Lapidge (1998) have dated this part after 820, judging on the inclusion in it of some passages taken from Amalarius of Metz's Liber officialis, but the piece has been dated at different points between the $8^{\text {th }}$ and the $12^{\text {th }}$ century.

8.2 John the Deacon in his Epistula ad Senarium ${ }^{5}$ quotes De Institutione I, 29. Here however hides another problem, because we do not know if the "Johannes Diaconus" author of the Epistula is a Roman deacon borne around 824, maybe monk of Motecassino and friend of Anastasius the Librarian's, or rather Pope John I (523-526) (Biographisch-Bibliographisches Kirchenlexikon, Johannes diaconus), in which case the borrowing must have taken the opposite direction.

8.3 The French noblewoman Dhuoda could have borrowed the etymology of scopeo from De Institutione I,5 (NEEL, 1991: 126, n. 156 to p. 39).

8.4 Cod. Paris, Bibliothèque Nationale, Lat. 2449 is a collection of canons copied in Lyon at the end of the $9^{\text {th }}$ century or beginnings of the $10^{\text {th }}$, which contains as well a short explanation of the episcopate influenced by De Institutione (REYNOLDS, 1975: 321-332; ZIMPEL, 1996: 117).

8.5 Archbishop's Wulfstan's Handbook, composed for the use of parish priests in hearing confession and determining penances in the early $11^{\text {th }}$ century (HEYWORTH: 2007; SAUER: 1980), contains among many other materials excerpts of book II of the De Institutione (see also above under the paragraph "The English connexion").

8.6 Gerbert of Aurillac, in his Libellus de corpore et sanguine domini draws brief paraphrases from 1,31 (ZIMPEL, 1996: 119). They are so short that do not constitute a real proof of Gerbert's acquaintance with Rabanus, but on the other side can be taken as a hint of the wide acceptance of Rabanus' handbook in clerical circles.

8.7 The Liber Quare (ed. G.P. GÖTZ: 1983) that originated in the surroundings of the school of St. Anselm of Laon (ca. 1050-1 117), con-

4 It was included by Johann Herwagen in his edition of Bede's Opera of Basel, 1563 (vol. 3, pp. 647-674), and later in Migne's PL 94, col. 539-562A. The most recent edition is due to Martha Bayless and Michael Lapidge (Scriptores Latini Hiberniae 14, Dublin, Dublin Institute for Advanced Studies, 1998). It is certainly not Bede's, but further is not possible to precise, and actually it has been dated between the 8 th and the 12th century.

5 Ed. Migne, PL 59, cols. 399-408, and more recently A. Wilmart, Analecta Reginensia, Studi e Testi 59, Vatican City, 1933, 19662, pp. 170-179. 
tains in its original recension some quotations from the De Institutione, that have been augmented in the later recension " $\mathrm{T}$ ", from around 1200. For example, Additio 29 follows closely De Institutione I, 14 23. Zimpel (1996: 124) points out to the possibility that this text could have been drawn not directly from the De Institutione Clericorum, but from Pseudo-Bede (ZIMPEL, 1996: 123-125).

8.8 In his De Sancta Trinitate Rupert of Deutz (Liège, ca. 1075-1 129) quotes Rabanus' De Institutione Clericorum I,7 (ZIMPEL, 1996: 125).

8.9 Ivo of Chartres' (ca. 1040-1115) Decretum and Panormia quote again from De Institutione I, 25 and 27-30 (ZIMPEL, 1996: 126-127). Since lvo is claimed to have studied at the Abbey of Bec, one tends to suspect that his acquaintance with Rabanus comes through Anselm of Laon.

8.10 Alger of Liège (1055-1131) (also known as Alger of Cluny and Algerus Magister) might have read De Institutione or parts of it for his De Sacramentis, although this is by no means sure.

8.11 Gratian's Decretum, written probably in Bologna in the $12^{\text {th }}$ century, quotes Rabanus' work no less than seven times by name and title, especially from book I, caps. 25, 27, 29 and 30 (ZIMPEL, 1996: 126).

8.12 Peter Lombard's Sententiarum libri IV quotes certainly from De Institutione I, 25 and 30, and probably also from II, 6 and 8 (ZIMPEL, 1996: 127-128).

8.13 Alexander of Hales' Summa (Alexandri de Hales Summa Theologica, ed. PERANTONI, 1948:144) uses material from the De Institutione, and even uses Rabanus as an authority in the typical quaestio structure, even against St. Augustine (ZIMPEL, 1996: 128).

8.14 Albertus Magnus' Commentary on the Sentences of the Lombard quotes Rabanus in relation to baptism and exorcisms (ZIMPEL, 1996: 128-130).

8.15 Thomas of Aquinas' Summa mentions Rabanus by name almost 400 times, fewer times less for example than Isidore of Seville, and also in his Catena aurea in Mattheum. Surely got Aquinas acquainted with Rabanus during the time he studied under Albertus Magnus in Cologne (ZIMPEL, 1996: 130-133).

8.16 Guilelmus Durantis uses again Rabanus De Institutione in his Rationale (1286), in the part dedicated to baptism (ZIMPEL, 1996: 133-134).

8.17 Durandus de St. Porciano, at the beginning of the $14^{\text {th }}$ century, uses also some paragraphs, but most probably he quotes indirectly, with Gratian's Decretum as his primary source (ZIMPEL, 1996: 134). 
8.18 Gabriel Biel (Speyer ca. 1429- 1495) draws from the De Institutione in his works Collectorium circa quattuor libros Sententiarum and Canonis misse expositio (ZIMPEL, 1996: 134-136).

\section{Conclusion: reception of the De Institutione Clericorum}

Rabanus work must have had an almost immediate reception in many ecclesiastical institutions of the Carolingian empire. To start with, its success is made evident by the mere existence of different recensions, since, besides the original one we have encountered the so-called Rhenish and " $F$ " recensions together with Archbishop Wulfstan's. And to those we must add the re-elaboration performed by Rabanus for his De Sacris Ordinibus, and in a lesser measure for his De Ecclesiastica Disciplina. In the same direction points the abundance of excerpts and fragments and reminiscences in later authors.

As a consequence of this success, the diffusion of the De Institutione Clericorum was fast and broad from the first years after its composition, as prove the more than one hundred witnesses mentioned in the previous pages.

Fulda and Mainz were the original nucleus from which the De Institutione Clericorum disseminated, and especially Fulda, because together with Rabanus' original (7.1) and the copy that he presented to archbishop Histulf (7.2), we still have manuscript M1 (1.1), which was copied in that scriptorium, which in spite of being a pretty careless copy, it was made in the first third of the $9^{\text {th }}$ century, and also the excerpts 2.2 from the middle years of the same century and the slightly later 2.3; and from Fulda were also the now lost $X 1$ (7.4), $Y 1$ (7.6), and 7.14, all from the $9^{\text {th }}$ century as well.

Then, from Fulda, Rabanus' work spread very quickly and with considerable success across the Carolingian empire. Traveling to the South-West, the De Institutione Clericorum arrived at Regensburg, where it was copied several times from the second quarter of the $9^{\text {th }}$ century, and that is the origin of the tween manuscripts M2 (1.2) and S (1.3). St. Emmeram also had copies of the De Sacris Ordinibus (5.3) in the $10^{\text {th }}$ century, and of the " $F$ " recension in the $11^{\text {th }}(4.11)$, and Prüfening was in possession of a complete De Institutione in the $12^{\text {th }}(7.22)$.

On its way to Regensburg, or maybe from there, our book came to the hands of bishop Humbert of Würzburg (7.15), who, given the enthusiasm he shows for it, must have used it for the education of his clerics. And still in the same general direction and within the limits of the $9^{\text {th }}$ century, the $D e$ Institutione Clericorum reached Salzburg because it was excerpted there (2.1) at some point before year 850 .

To the North, the De Institutione Clericorum was adapted in the so-called Rhenish recension not later than 850 because 3.1 is from the second third 
(or at most the third third) of the $9^{\text {th }}$ century. And the same recension was copied in Trier (3.3) and Cologne (3.2), and both copies are from the $9^{\text {th }}$ century too (apart from several others that come from the $13^{\text {th }}$ century), but the original text was also known in this area, at least in Cologne, in the $10^{\text {th }}$ century (1.6).

Also from Fulda, or maybe from Mainz, the text traveled to the South. It was in Lorsch before the end of the $9^{\text {th }}$ century (7.16), and somewhere in that area it was reworked and abbreviated in the " $\mathrm{F}$ " recension, since its oldest witnesses come from Bodensee (4.3), Reichenau (4.1), Sankt-Gallen (4.4) and other centers of South Germany $(4.5,4.6)$, and finally it arrived in Upper Italy (4.2). ${ }^{6}$

To the West of Mainz the dissemination seems to have been somewhat slower, but in any case, Fi (1.5) was there as early as the third quarter of the $9^{\text {th }}$ century, after suffering some reorganization of the materials. And still within the limits of the $9^{\text {th }}$ century we find the De instituione in Trier, in the so-called Rhenish recension (3.3) and Metz (5.2) (actually these two cases are copies of the De Sacris Ordinibus).

Still further to the South-West, we find copies in Bourges (P1 0 1.4) and Lyon (8.4), and it is possible that it was in this area where the noble lady Dhuoda (8.4) had the chance to read it. But there are more pieces of evidence of the presence of the De Institutione on French floor already in the $9^{\text {th }}$ century (Y3=7.9).

During the $10^{\text {th }}$, in spite of all its turbulence and convulsions, the De Institutione Clericorum kept on spreading although not so spectacularly.

To the North, it reached Braunsweig (4.7), and Rheims, in France, where Gerbert of Aurillac could see it (8.6), 7 and also Angers $(A n=1.7)$ and Mois$\operatorname{sac}(Y 4=7.10)$.

Y6 (7.12) can also be considered of French origin and from the 10th century. However, the most significant advance was to the South, since the book is found in North Italy (4.8), to reach Rome at some point near the year 1000 (2.5).

Then, in the $11^{\text {th }}$ century, we find many instances of the De Institutione Clericorum in the already mentioned areas, but especially it advanced in direction North-West: Liege, where we find it in the hands of Rupert of Deutz

6 In the map this manuscript has been assigned to Aosta simply for convenience, but its place of origin can be any other center of this area.

7 To be honest, it is impossible to ascertain that Gerbert had known the De Institutione directly, and if so if he had seen it in Rheims, but this is the most plausible possibility, seems Catalonia seems too far away from the primordial diffusion area of the De Institutione. 
(8.8), and Bec $(8.7,8.9),{ }^{8}$ and, of course, in England, where it was used by Archbishop Wulfstan of York, and were another brand of the transmission is found (6.1-6.4).

Finally, in the $12^{\text {th }}$ century, Rabanus' text had arrived in Esrom, in Denmark (2.9).

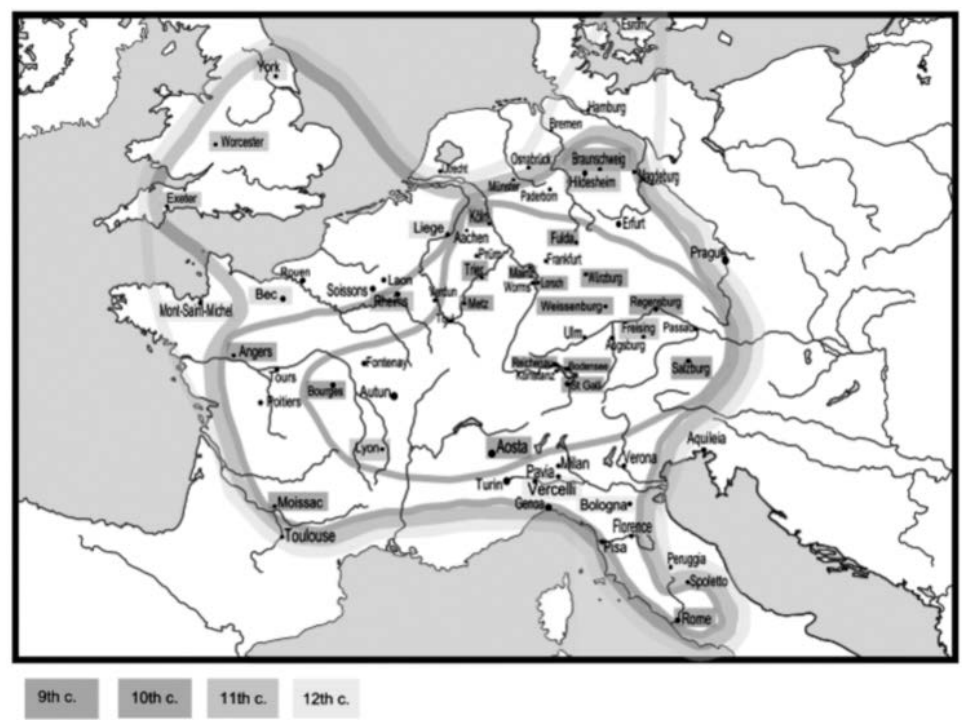

\section{Addenda: Editions and translations of the De Institutione Clericorum}

\section{Georgius Simler}

The first printed edition of the De Institutione Clericorum came to light in as soon as 1504 in Pforzheim. The early date can be taken as a token of the esteem Rabanus Maurus held in. The complete title was: Rabani Mauri Archiepiscopi Maguntini De Institutione Clericorum opusculum aureum.

But for this edition Georg Simler used mainly Codex Düsseldorf, B 1 13, and

8 That St. Anselm had seen the De institutione clericorum in Bec is an assumption based on the fact that Ivo of Chartres studied there with St. Anselm. It seems therefore a more "economic" option than considering that St. Anselm and lvo had 'known the De institutione independently from each other. 
Trier, 592/1578, which does not transmit Rabanus' original recension, but the so-called Rhenish recension, but because the manuscripts on which he based his edition do not contain an otherwise characteristic alteration in chapter I,32, it is also missing in it. And because his manuscript contained the "Additio de missa," it is also in Simler's edition.

But Georg Simler did not publish just one edition of the De Institutione, but two. Scarcely one year after the first one had left the presses, Simler came to another manuscript that transmitted Rabanus' original recension and published it in 1505 with the title of Hrabani Mauri De Institutione Clericorum libri tres, also in Pforzheim.

The manuscript that served Simler as a reference for this second edition is not known. It certainly had a peculiar arrangement of the preliminary pieces, and for its readings, it was very close to $\mathrm{Y} 2$ in the stemma codicum (ZIMPEL, 1996: 144-145). If it contained the "Additio de missa" is another question. It was certainly included in this 1505 edition, but Simler knew it from the previous one; therefore, if he found it in his exemplar or took it from the Rhenish recension will remain in the darkness.

\section{Johannes Prael}

A new edition of the De Institutione appeared Cologne in 1532, this time Johannes Prael and under the title of Rabani Mauri Maguntinensis Archiepiscopi de clericorum institutione et sermone et ceremoniis Ecclesiae, ex Veteri et Novo Testamento, ad Heistulphum Archiepiscopum libri III.

For his edition Prael used a now lost manuscript very near the archetype that in its variants was also very close to the present $\mathrm{K} 1$, although the preliminary pieces were in a different order: preface to the brethren of Fulda, dedication to archbishop Haistulf and list of chapters (ZIMPEL, 1996: 146147). However, Prael used K1 as well, and therefore his edition doesn't make possible to reconstruct that lost manuscript.

\section{Melchior Hittorp}

The next edition is due to Melchior Hittorp who published in Cologne in 1568 his De divinis Catholicae Ecclesiae officiis ac ministeriis, varii vetustorum aliquot ecclesiae Patrum ac Scriptorum libri (309-382).

In the prologue to this edition, Hittorp specifies that in order to reconstruct Rabanus' text he used, together with the already existing editions, two manuscripts from the Cathedral library of Cologne, none of which had the "Additio de missa," which he must have therefore taken from Prael or Simler. Now, the only manuscript with this characteristic that survives in Cologne 
is Erzbischöfliche Diözesan- und Dombibliothek, 110; therefore one must assume that the other one has perished, and that regretful event must have taken place already before 1752, since it is not mentioned in the 1752 catalog of the Cathedral Library of Cologne (HUISH, 1752). And as in the case of Prael's edition, it is not possible to reconstruct that lost manuscript from Hittorp's, because also used the pre-existing editions, and he doesn't specify how. The only thing that can be ascertained is that it must have had some readings similar to those of the origins of the $\mathrm{X}$ branch of the stemma (ZIMPEL, 1996: 148-149).

Hittorp's text was reprinted in 1591 in Rome by Ferrari and in 1610 and 1624 in Paris, in the latter occasion under the title De divinis Catholicae Ecclesiae officiis et mysteriis, varii vetustorum aliquot ecclesiae Patrum ac Scriptorum libri, and then the same text was used again in the Magna Bibliotheca veterum patrum (Paris, 1644).

\section{George Colvener}

The next edition went in charge of George Colvener in 1626/27. Again he took as a departure point a manuscript of the $Y$ side of the stemma, although it is difficult to ascertain which one, but he relied heavily on Prael's edition (ZIMPEL, 1996: 150-151).

Colvener's edition was reprinted with very scarce and small modifications in the Patrologia Latina of Migne (vol. 107, cols. 293-420A).

\section{Alois Knoepfler}

The first proper critical edition is that of Alois Knoepfler of Munich, 1900. Knoepfler not only used all the manuscripts known in his time (except Fi), but he also provides a critical apparatus and a study of the sources. It is good enough to have served as a standard reference for almost a hundred years.

\section{Detlev Zimpel}

The latest edition is due to Detlev Zimpel and saw the light in 1996. Zimpel's is a meticulous work that taking $\mathrm{K} 1$ as Leithandschrift, uses all the previous editions as well as all the manuscripts available, including those that in the time of Knoepfler were not known, and provides all the variant readings as well as a stemma codicum and a detailed analysis of the sources.

Unless we had the fortune of finding a new codex still unknown which turned to be really very close to the archetype, it is difficult to think off a more exact edition than this one. 


\section{Translations}

To our knowledge, up to this moment, De Institutione Clericorum has been translated to three modern languages.

The first translation, to Italian, is due to Luigi Samarati (2002). It was made taking as departure point Detlev Zimpel's edition of 1996 and is preceded by a brief introduction (p. 5-19) with a summary of Rabanus' biography and a sketch of his work. This text adds as well a simplified apparatus fontium and some explanatory notes.

The second translation, to German, is due to Detlez Zimple (2006). It is actually a bilingual edition in Latin and German on a double page setting, with the Latin text (which is identical to the edition of 1996) at the left and the German translation at the right. Although the apparatus fontium reproduces the one included in the edition of 1996, it also has some new additions, but the critical apparatus is missing. The introduction reproduces as well the introduction from the edition of 1996.

Finally, the third translation, into Spanish, is due to the same author of this article and was the Ph. D. dissertation defended in the Madrid, Universidad Nacional de Educación a Distancia (UNED) in 2014. It comes also in a double page setting, with the Latin text on the left page and the Spanish translation on the right page. The critical apparatus included is for the most part taken from Zimpel (with his approval), but it has been simplified, although the variant readings from the most important editions have been added. The Spanish text is accompanied by explanatory notes that deal in depth with subjects that are not easily understandable by the modern reader, and everything is preceded by a lengthy introductory study. In brief, this work will be published by the Biblioteca de Autores Cristianos, in Madrid.

\section{References}

BAYLES, Martha \& LAPIDGE, Michael (eds.) (1998): Collectanea Pseudo-Bedae. Scriptores Latini Hiberniae, Dublin, Dublin Institute for Advanced Studies. BECKER, Gustav (1885): Catalogi bibliothecarum antiquii, Bonnae, Fr. Cohen. GÖTZ, Georg P. (ed.) (1983): Liber Quare, Corpus Christianorum Continuatio Medievalis 60, Burnhout, Brepols.

HEYWORTH, Melanie (2007): "The late old English Handbook for the use of a Confessor: authorship and connections", Notes and Queries, 54/3, pp. 218-222.

HITTORP, Melchior (1568): De divinis Catholicae Ecclesiae officiis ac ministeriis, varii vetustorum aliquot ecclesiae Patrum ac Scriptorum libri, Cologne. KNOEFLER, Alois (1900): Hrabanus Maurus. De Institutione Clericorum, München. 
KOTTJE, Raimund (1075): "Rabanus Maurus - Praeceptor Germaniae?", Deutsches Archiv für Erforschung des Mittelalters, 31, pp. 534-545.

LEHMANN, Paul (1918): Mittelalterliche Bibliothekskataloge Deutschlands un der Schweiz. I. Band. Die Bistümer Konstanz und Chur, München, Bayerische Akademie der Wissenschaften - C.H. Beck.

LEHMANN, Paul (1962): "Corveyer Studien", in Paul Lehmann, Erforschung des Mittelalters. Ausgewählte Abhandlungen und Aufsätze, vol. 5, pp. 94-178. Stuttgart.

MIGNE, Jacques-Paul (1844-): Patrologia Latina cursus completus, Paris. NEEL, Carol (1991): Handbook for William. A Carolingian Woman's Counsel for her Son, Washington DC, The Catholic University of America Press.

PERANTONI, Pacifici M. (ed.) (1948): Doctoris irrefragabilis Alexandri de Hales, ordini minorum Summa theologica : seu sic ab origine dicta "Summa fratris Alexandri / Tomus IV, Liber tertius (textus). Ad Claras Aquas (Quaracchi), Ex typ. Collegii S. Bonaventurae.

REYNOLDS, Roger E. (1975): "A Ninth-Century Treatise on the Origins, Office, and Ordination of the Bishop", Revue Bénédictine, 85, pp. 321-332.

RUF, Paul (1933): Mittelalterliche Bibliothekskatalogue Deutschlands un der Sweiz III, 2, Bistum Eichstätt, München.

SAMARATI, Luigi (trans.) (2002): La formazione dei chierici di Rabano Mauro, Roma, Cittá Nuova.

SÁNCHEZ-PRIETO, Ana B. (2014): Rabano Mauro, Sobre la Educación de los Clérigos (De institutione clericorum). Alcance y penetración de la escuela carolingia, Ph. D. Dissertation, Madrid, Universidad Nacional de Educación a Distancia.

SÁNCHEZ-PRIETO, Ana B. (2018): "Hrabanus Maurus' De institutione clericorum: Teaching Theology, Liturgy and Liberal Arts in Carolingian Germany", Studia Monastica, 60/1, pp. 27-62.

SAUER, Hans (1980): "Zur Überlieferung und Anlage von Erzbischof Wulfstan, Handbuch", Deutsches Archiv für Erforschung des Mittelalters, 36, pp. 341-384. WILMART, André (1933, 1966²): Analecta Reginensia. Studi e Testi, 59, Vatican City.

ZIMPEL, Detlev (ed.) (1996): "Rabanus Maurus, De Institutione Clericorum libri tres", Frankfurt a.M.-Berlin-Bern, Peter Lang Verlag.

ZIMPEL, Detlev (trans) (2006): "De Institutione Clericorum: Über die Unterweisung der Geistlichen", Fontes Christiani 61, Turnhout, Brepols. 